\title{
Indocyanine Green Videoangiography for Vessel Identification and Preservation Prior to Dural Opening for Microvascular Decompression
}

\author{
Mikrovasküler Dekompresyon için Duranın Açılması Öncesinde Damar \\ Tanumlama ve Koruma için Indosiyanin Yeşil Videoanjiyografisi
}

\author{
Kunio YOKOYAMA ${ }^{1}$, Masahiro KAWANISHI ${ }^{1}$, Makoto YAMADA $^{1}$, Hidekazu TANAKA ${ }^{1}$, Yutaka ITO ${ }^{1}$, \\ Toshihiko KUROIWA ${ }^{2}$ \\ ${ }^{1}$ Takeda General Hospital, Department of Neurosurgery, Fushimi, Kyoto, Japan \\ ${ }^{2}$ Osaka Medical College, Department of Neurosurgery and Department of Surgical Pathology, Takatsuki, Osaka, Japan
}

Corresponding Author: Kunio YOKOYAMA / E-mail: neu100@poh.osaka-med.ac.jp

\begin{abstract}
Unexpected bleeding from the dural sinus can sometimes occur when performing a dural opening during microvascular decompression. We conducted dural opening safely by performing indocyanine green (ICG) videoangiography before making a dural incision. We introduce two specific cases in which surgery was performed to treat a trigeminal neuralgia. In both cases, a small craniectomy was performed in the transverse-sigmoid junction. ICG $(0.25 \mathrm{mg} / \mathrm{kg}$ dose) was administered intravenously just prior to dural opening. Using a microscope equipped with fluorescent filters, real-time flow assessment of the underlying veins was done. ICG videoangiography allowed for a clear confirmation of the margins of the dural sinus as well as the vascular structures at the surface of the cerebellum, which were clearly seen through the dura mater. Performing ICG videoangiography prior to dural opening makes it possible to safely perform dural opening.
\end{abstract}

KEYWORDS: Indocyanine green videoangiography, Microvascular decompression, Dural opening

öz

Mikrovasküler dekompresyon sırasında dura açılırken bazen dural sinüsten beklenmeyen kanama oluşabilir. Bir dura insizyonu gerçekleştirmeden önce indosiyanin yeşil (ICG) videoanjiyografisi yaparak durayı güvenli bir şekilde açtık. Trigeminal nevralji tedavisi için ameliyat edilen iki olgu sunuyoruz. Her iki olguda transvers-sigmoid bileşkede küçük bir kraniyektomi yapıldı. Duranın açılmasından hemen önce intravenöz olarak ICG $(0,25 \mathrm{mg} / \mathrm{kg}$ doz) uygulandı. Floresan filtrelerle donatılmış bir mikroskop kullanılarak altta yatan venlerde akış gerçek zamanlı olarak değerlendirildi. ICG videoanjiyografi dural sinüsün kenarlarının ve ayrıca dura mater içinden açıkça görünen serebellum yüzeyi vasküler yapılarının net bir şekilde doğrulanmasını mümkün kıldı. Duranın açılmasından önce ICG videoanjiyografi yapılması, duranın güvenli bir şekilde açılmasını mümkün kılar.

ANAHTAR SÖZCÜKLER: İndosiyanin yeşil videoanjiyografisi, Mikrovasküler dekompresyon, Duranın açılması

ABBREVIATIONS: ICG: indocyanine green, MVD: microvascular decompression

\section{INTRODUCTION}

Microvascular decompression (MVD) surgery is a therapeutic method established for the treatment of trigeminal neuralgia and facial spasm cases. In this surgical procedure, the approach to the lesion is realized by performing a small craniectomy in the vicinity of the dural sinus in the posterior fossa, and by performing a dural opening very close to the margins of the dural sinus. However, since the margins of the dural sinus may be difficult to confirm even by using a microscope, unexpected bleeding may also sometimes occur. Although bleeding from the dural sinus is usually dealt with by performing pressure hemostasis alone, there is a risk of air embolism and sinus thrombosis due to the hemostatic procedure $(2,8)$. By conducting indocyanine green (ICG) videoangiography prior to performing an incision in the dura mater, we have made it possible to clearly see the margins of the sinus, and as a result, we have been able to safely perform dural opening. We report two specific cases that we treated in our hospital.

\section{CASE REPORTS}

All patients were cleared for a history of iodine allergy and previous anaphylactic reactions to contrast media or dye injections. In each case, a peripheral intravenous ICG dose of 
$0.25 \mathrm{mg} / \mathrm{kg}$ was injected as a bolus once the dura had been exposed. The venous structures were visualized in real time and marked, allowing strategic planning of the dural opening. There were no obvious complications, and the ICG worked well in each case, nicely illuminating the venous anatomy through the intact dura.

\section{Case 1:}

The patient was a 68-year-old male who was surgically treated by using the right lateral suboccipital approach because of pain, which had persisted for three years, in the area of the third branch of the right trigeminal nerve. The dura mater was exposed by performing craniectomy in the retromastoid area. The right transverse sinus could be confirmed vaguely through the dura mater, but its margins could not be identified. ICG $(0.25 \mathrm{mg} / \mathrm{kg}$ dose) was administered intravenously just prior to dural opening. Using a microscope equipped with fluorescent filters, real time flow assessment of underlying veins was done. First, visualization of the blood vessels at the surface of the brain and cerebellar hemispheres was achieved; next, the transverse sinus and its margins were also successfully confirmed. Dural opening at a location extremely close to the transverse-sigmoid junction was achieved without causing any bleeding from the dural sinus, and without causing damage to the veins at the surface of the cerebellum. As a result, sufficient surgical field was successfully secured and MVD could be safely performed (Figure 1A-C).

\section{Case 2:}

The patient was a 66-year-old female who underwent surgery by using the left lateral suboccipital approach for the treatment of pain, which had persistent for two years, in the area of the third branch of the left trigeminal nerve. The dura mater was exposed by performing craniotomy in the retromastoid area. The transverse sinus was confirmed vaguely, but as expected its margins were unclear, and the veins at the surface of the brain could not be confirmed. ICG videoangiography was performed, and as a result, in the same manner as in Case 1, visualization of the cerebellar cortical vein was confirmed, and later, the transverse sinus and its margins were also clearly confirmed tardively. Dural opening was successfully and safely performed, up to a site extremely close to the transverse-sigmoid junction, and was achieved without causing any bleeding from the sinus (Figure 1D-F).

\section{DISCUSSION}

Minimally invasive surgery has recently become important even in craniotomies for the treatment of lesions in the cranial fossa, particularly in MVD for the treatment of facial spasm
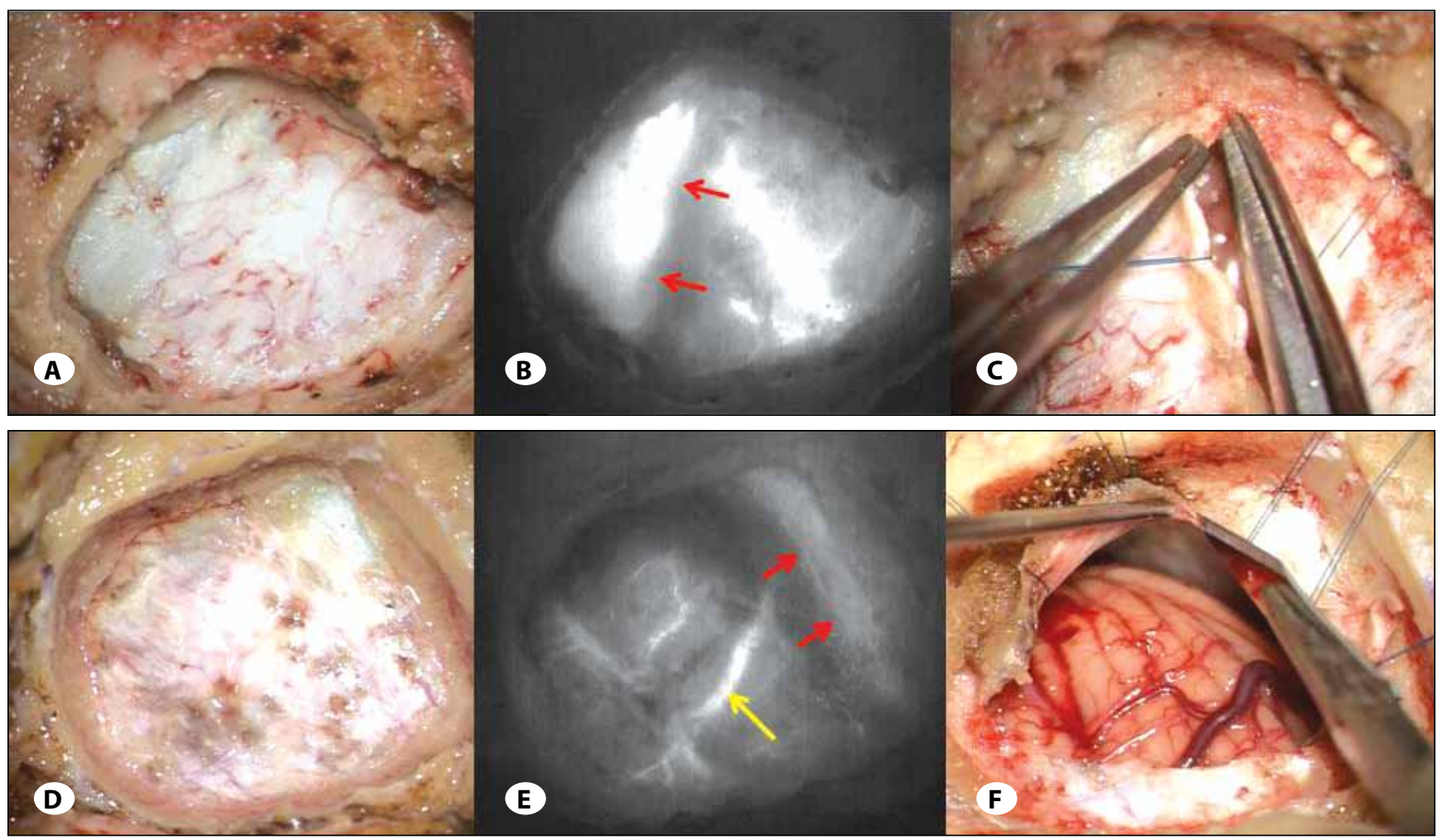

Figure 1: Intraoperative photographs of bone window and indocyanine green videography. (A-C: Case 1, D-F: Case 2) A) Intraoperative photograph of craniectomy in case 1. B) Intraoperative indocyanine green videography demonstrates right transverse sinus (red arrow) and cortical cerebellar vein. C) Dural incision was performed in the direction of right transverse-sigmoid junction. D) Intraoperative photograph of craniectomy in case 2. E) Intraoperative indocyanine green videography demonstrates left transverse sinus (red arrow) and cortical cerebellar vein (yellow arrow). F) Dural incision was performed in the direction of left transverse-sigmoid junction. 
and trigeminal neuralgia, and extremely small craniotomies have therefore been performed. The surgical field is deep and narrow, particularly in MVD for the treatment of trigeminal neuralgia and the dural incision therefore has to be made extremely close to the margins of the transverse-sigmoid junction. The margins of the sinus can sometimes be unclear even under a microscope. If an incision is accidentally made in the sinus and bleeding occurs, there is a risk of air embolism and sinus thrombosis associated with the hemostatic procedure $(2,8)$. Even if the surgery is conducted under a microscope, the margins of the sinus need to be clearly visualized in real time to conduct a dural opening safely without injuring the sinus.

Indocyanine green videoangiography has been widely used in ophthalmology to assess the retinal microcirculation $(7,9)$. In the field of neurosurgery, the use of ICG videoangiography has been reported for the confirmation of patency of the parent vessel during the surgical clipping of cerebral aneurysms, for the confirmation of flow patency during bypass surgery, and for the intraoperative visualization of vascular anomalies in arteriovenous malformation (AVM) patients (1,3,4-6,10-13). However, to the best of our knowledge, no study has yet reported the usefulness of ICG videoangiography in dural openings in the posterior fossa. Conducting ICG videoangiography before performing dural opening allows a very clear visualization of the margins of the dural sinus and vascular structures at the surface of the brain, and as a result, damage to these elements can be prevented during dural opening. This simple technique can potentially prevent a severe venous infarction by avoiding inadvertent sinus injury.

\section{REFERENCES}

1. Awano T, Sakatani K, Yokose N, Kondo Y, Igarashi T, Hoshino T, Nakamura S, Fujiwara N, Murata Y, Katayama Y, Shikayama T, Miwa M: Intraoperative EC-IC bypass blood flow assessment with indocyanine green angiography in moyamoya and nonmoyamoya ischemic stroke. World Neurosurg 73(6):668-674, 2010

2. Crocker M, Nesbitt A, Rich P, Bell B: Symptomatic venous sinus thrombosis following bone wax application to emissary veins. Br J Neurosurg 22(6):798-800, 2008

3. Esposito G, Durand A, Van Doormaal T, Regli L: Selectivetargeted extra-intracranial bypass surgery in complex middle cerebral artery aneurysms: Correctly identifying the recipient artery using indocyanine green videoangiography. Neurosurgery 71(2 Suppl Operative):ons274-284, 2012
4. Faber F, Thon N, Fesl G, Rachinger W, Guckler R, Tonn JC, Schichor C: Enhanced analysis of intracerebral arterioveneous malformations by the intraoperative use of analytical indocyanine green videoangiography: Technical note. Acta Neurochir (Wien) 153(11):2181-2187, 2011

5. Ferroli P, Nakaji P, Acerbi F, Albanese E, Broggi G: Indocyanine green (ICG) temporary clipping test to assess collateral circulation before venous sacrifice. World Neurosurg 75(1):122-125, 2011

6. Ma CY, Shi JX, Wang HD, Hang CH, Cheng HL, Wu W: Intraoperative indocyanine green angiography in intracranial aneurysm surgery: Microsurgical clipping and revascularization. Clin Neurol Neurosurg 111(10):840-846, 2009

7. Mutoh T, Sakurai M, Tamai M: Indocyanine green fundus angiography of retrobulbar vasculature. Arch Ophthalmol 113(5):631-633, 1995

8. Ohata K, Haque M, Morino M, Nagai K, Nishio A, Nishijima Y, Hakuba $A$ : Occlusion of the sigmoid sinus after surgery via the presigmoidal-transpetrosal approach. J Neurosurg 89(4): 575-584, 1998

9. Ohno-Matsui K, Morishima N, Ito M, Yamashita S, Futagami S, Tokoro T, Nakagawa T: Indocyanine green angiography of retrobulbar vascular structures in severe myopia. Am J Ophthalmol 123(4):494-505, 1997

10 . Suzuki K, Mikami T, Sugino T, Masahiko W, Miyamoto S, Hashimoto N, Mikuni N: Discrepancy between voluntary movement and motor-evoked potentials in evaluation of motor function during clipping of anterior circulation aneurysms. World Neurosurg pii: S1878-8750(13)01065-6, 2013

11. Takagi Y, Kikuta K, Nozaki K, Sawamura K, Hashimoto N: Detection of a residual nidus by surgical microscopeintegrated intraoperative near-infrared indocyanine green videoangiography in a child with a cerebral arteriovenous malformation. J Neurosurg 107 Suppl 5:416-418, 2007

12. Washington CW, Zipfel GJ, Chicoine MR, Derdeyn CP, Rich KM, Moran CJ, Cross DT, Dacey RG Jr: Comparing indocyanine green videoangiography to the gold standard of intraoperative digital subtraction angiography used in aneurysm surgery. J Neurosurg 118(2):420-427,2013

13. Woitzik J, Horn P, Vajkoczy P, Schmiedek P: Intraoperative control of extracranial-intracranial bypass patency by nearinfrared indocyanine green videoangiography. J Neurosurg 102(4):692-698, 2005 